\title{
Sorgens pris:
}

\section{En litteraturgennemgang af konsekvenserne ved at miste en forælder $i$ barndommen}

\author{
Atle Dyregrov ${ }^{1} \&$ Martin Lytje $^{2}$ \\ ${ }^{1}$ Senter for krisepsykologi, Bergen \\ atle@krisepsyk.no \\ ${ }^{2}$ Kræftens Bekæmpelse \\ martin@lytje.org
}

Dyregrov, Atle; Lytje, Martin (2018). 'Sorgens pris: En litteraturgennemgang af konsekvenserne ved at miste en forælder i barndommen' i Tidsskrift for Forskning i Sygdom og Samfund, nr. 29, 27-54.

Igennem det sidste årti er der i forskningsverdenen opnået bred enighed om, at forældretab $i$ barndommen har altomfattende konsekvenser. Det inkluderer, at sorgramte børn oftere pådrager sig psykiske, fysiske, sociale og faglige udfordringer senere i livet. Udfordringerne kan ved livstruende sygdom spores allerede i tiden op til dødsfaldet, ligesom de er synlige, $i$ tiden efter dødsfaldet. Selvom de fleste af sådanne reaktioner reduceres med tiden, forbliver andre vedvarende.

Denne artikel ønsker igennem en litteraturanalyse at formidle konsekvenserne af at miste en forælder som barn. Dette sker primært ud fra de sidste to årtiers forskning og igennem en præsentation af de undersøgelser, der har beskxftiget sig med de fysiske, psykologiske, pædagogiske og sociale konsekvenser af forældretab i barndommen. Der vil $i$ artiklen være fokus på at evaluere både studiernes begrænsninger såvel som kvalitet. Artiklen er forfattet som en narrativ oversigtsartikel, der beskriver de vigtigste studier på området og vurderer disse ud fra forfatternes forsknings- og kliniske erfaring. 
Living with grief: A literature review on the consequences of losing a parent during childhood

Approximately $4 \%$ of all children in the Western world lose one or both parents before the age of 18. Over the past decade, there has been an increasing consensus among researchers that this experience can have all-encompassing consequences. Bereaved children have an increased risk of developing psychological, physical, social and educational challenges later in life. In the case of life-threatening diseases, these challenges may already be identified during the period preceding the loss and as well as in the time following bereavement. Through a literature analysis primarily based on the last two decades of research, this article examines the consequences of childhood bereavement. This is done through a presentation of studies that have investigated the psychological, physical, social, health-related challenges, as well as the educational implications associated with a loss in childhood. The study focuses on presenting selected research publications and discussing the limitations and quality of these.

\section{Introduktion}

Når et barn mister en forælder, forandres livet for altid. Den verden, der ofte virkede sikker og forudsigelig, bliver pludselig fremmed, skræmmende og uforudsigelig (Green \& Connolly, 2009). I tiden efter tabet af en forælder kan det være umuligt at forestille sig, hvordan man nogensinde skal kunne genfinde livsglæden og komme videre i livet. I denne forbindelse har en rapport fra US Bureau of the Census (1990) fundet, at omkring $4 \%$ af alle børn i den vestlige verden mister en eller begge forældre, før de fylder 18. Langt de fleste af disse børn og unge klarer sig igennem deres sorg ved hjælp af støtte fra positive netværk og ressourcer (fx venner, fritidsinteresser, familie) i deres nærmiljø (Williams \& Aber, 2016). Gruppen har dog som helhed langt flere risici for at opleve udfordringer i livet. Samtidigt er børn i en situation, hvor de er meget afhængige af, hvordan den overlevende forælder håndterer tabet. Dette giver naturligvis yderligere udfordringer, især hvor forældreevnen hos den overlevende forælder svækkes (A. Dyregrov, 2008; Holland, 2001).

Igennem det sidste årti er der således opstået bred enighed blandt forskere om, at forældretab i barndommen har altomfattende konsekvenser. Det inkluderer, at sorgramte børn har forhøjet risiko for at pådrage sig psykiske, fysiske, sociale og faglige udfordringer i livet. Udfordringerne kan ved livstruende sygdom spo- 
res allerede i tiden op til dødsfaldet (fx Lytje, 2016b; Phillips, 2014) ligesom de er synlige i tiden efter dødsfaldet (fx Dowdney, 2000; Nielsen, Sørensen, \& Hansen, 2012). Selvom de fleste af sådanne reaktioner reduceres med tiden, forbliver andre vedvarende.

Formålet med denne artikel er igennem en litteraturanalyse at formidle konsekvenserne af at miste en forælder som barn, primært ud fra de sidste to årtiers forskning. Det gør vi igennem en præsentation af de undersøgelser, der har beskæftiget sig med de fysiske, psykologiske, sociale og uddannelsesmæssige konsekvenser af forældretab i barndommen. Vi vil igennem artiklen have fokus på at evaluere både studiernes begrænsninger og kvalitet.

\section{Metode}

Denne artikel er forfattet som en narrativ oversigtsartikel (NO). Ifølge MaClure (2005) er NO'er akademiske litteraturgennemgange, der præsenteres sammenhængende med en fortolkning og kritik af det område, de gennemgår. NO'er er særligt effektive til at skabe overblik over et større felt frem for at gå i dybden med enkelte og specifikke områder indenfor feltet (Mulrow \& Cook, 1998). I denne artikel undersøger vi fysiske, psykiske, sociale og uddannelsesmæssige udfordringer ved tabet af en forælder, frem for kun et af disse områder. Målet med narrative analyser er ifølge Mays, Pope og Popay (2005) at sammenfatte, forklare og fortolke et forskningsemne igennem inddragelsen af kvalitative og kvantitative studier. Formålet med NO er således at præsentere en autoritativ gennemgang, der er baseret på en selektiv udvælgelsesproces og fremstår troværdig overfor en læserskare af ligesindede eksperter. NO'er er derfor ikke underlegne versioner af systematiske litteraturgennemgange, men en alternativ og komplementær form for litteraturanalyse (Greenhalgh, Thorne \& Malterud, 2018).

Selvom metoden er et effektivt værktøj til at skabe overblik over et felt, har den ofte være kritiseret for at lægge for stor vægt på hyppigt citerede artikler frem for den nyeste forskningsviden (Mulrow \& Cook, 1998). For at sikre at dette ikke blev et problem i denne artikel, baserede vi litteraturgennemgangen på en større systematisk litteratursøgning med fokus på at forholde os til de fire områder: fysiske, psykiske, sociale og uddannelsesmæssige udfordringer i forbindelse med forældertab i barndommen. Tilgangen skabte et solidt fundament til at forfatte en deskriptiv og reflekteret evaluering af området og den viden, vi har om konsekvenserne af forældretab i barndommen. Derudover blev der igennem skrivepro- 
cessen løbende suppleret med mindre litteratursøgninger for at sikre, at helt nye studier ikke blev overset inden for de specifikke områder.

Forskningen, der har beskæftiget sig med tab i barndommen, har længe været stærkt forankret inden for psykologi og pædagogisk psykologi. Derfor vil denne gennemgang hente de fleste af sine artikler fra disse områder, samtidig med at undersøgelser fra områder som medicin og psyko-onkologi også inddrages. I et forsøg på at give et nutidigt syn på den aktuelle tilstand af viden om konsekvenserne ved forældretab fokuserer denne gennemgang primært på litteratur forfattet i dette årti. Undtagelser fra dette sker, når ældre undersøgelser har fundet betydelige resultater, der ikke er genskabt i senere studier. Du kan finde en oversigt over den komplette datagenerering i tabel 1.

\begin{tabular}{|l|l|}
\hline Skridt & Datagenereringsprocedure \\
\hline $\mathbf{1 .}$ & $\begin{array}{l}\text { En tidligere litteraturgennemgang foretaget af Lytje (2016) blev } \\
\text { brugt som grundlag for denne artikel. Grundlaget omfattede en } \\
\text { systematisk gennemgang, der dækker 385 artikler. }\end{array}$ \\
\hline $\mathbf{2 .}$ & $\begin{array}{l}\text { Ved hjælp af Google Scholar blev der foretaget yderligere søgninger } \\
\text { baseret på de vigtigste temaer i denne gennemgang og informeret } \\
\text { igennem de erfaringer, der var gjort igennem skridt 1. }\end{array}$ \\
\hline $\mathbf{3 .}$ & $\begin{array}{l}\text { Baseret på erfaringerne fra tidligere anmeldelser blev nøgle- } \\
\text { tidsskrifter (Death Studies, Bereavement Care) afsøgt for nye } \\
\text { publikationer. }\end{array}$ \\
\hline 4. & $\begin{array}{l}\text { Igennem Google Scholar blev det undersøgt, hvilke artikler der } \\
\text { havde refereret tidligere fundne nye studier. Dette gjorde det } \\
\text { muligt at finde frem til relevante artikler der ikke var blevet fundet } \\
\text { igennem tidligere skridt eller publiceret i kendte journaler. }\end{array}$ \\
\hline
\end{tabular}

Tabel 1: Litteratursøgningsproces

Artikler blev inkorporeret, hvis de var forfattet inden for et af de emner, der gennemgås i denne litteraturgennemgang (psykosocial, fysisk, helbred eller uddannelse) og som minimum havde en akademisk standard, der gjorde, at eventuelle metodiske svagheder kunne spores.

Rent konkret var udvælgelsen af litteratur centreret omkring fremvisningen af nye empiriske studier inden for forskningen om børns oplevelser i forbindelse med forældretab. Sådan forskning har traditionelt set været stærkt indlejret inden for de psykologiske og pædagogisk-psykologiske forskningsfelter. Derfor trækkes artikler primært fra disse områder såvel som igennem inklusion af empiriske 
studier fra medicin og psykoonkologi. Selvom der findes mange interessante teoretiske bidrag fra felter såsom antropologi og sociologi, har vi valgt at nedprioritere disse til fordel for empiriske evidensstudier. Helt konkret blev alle artikler gennemgået for 1) empirisk relevans, 2) målgruppe relevans, 3) metodisk validitet. Alle studier skulle således have en relevant målgruppe, en metodisk grundighed samt være empirisk funderede og relevante for litteraturgennemgangens udvalgte områder. Det blev prioriteret at artiklerne samtidigt var forfattet i dette århundrede (2000+), men i visse tilfælde inkluderes ældre studier, når de har en særlig stor relevans, der ikke er genskabt sidenhen.

Denne artikel har dermed til formål at præsentere et samlet overblik over, hvad vi i dag ved om de konsekvenser, der følger med tabet af en forælder i barndommen - med særligt fokus på det danske samfund. Der vil således både blive refereret til danske studier og internationale undersøgelser, når de findes relevante i forhold til den danske kontekst. Artiklen vil få steder gøre brug af litteratur, der ikke direkte har undersøgt børn med forældretab. Det sker i tilfælde, hvor der kun eksisterer lidt eller ingen litteratur direkte tilknyttet artiklens primære målgruppe. Her vil vi, når det er relevant, inkludere data fra andre sorgramte og diskutere, hvad de kan.

\section{Psykosociale konsekvenser}

I dette afsnit gennemgår vi de psykosociale konsekvenser af at miste en forælder som barn. Mere specifikt går vi særligt i dybden med risikoen for psykiske reaktioner, klinisk depression, sociale konsekvenser, livsglæde og risikobetonet adfærd.

\section{Psykiske reaktioner}

Tabet af en forælder i barndommen har i et historisk perspektiv længe været associeret med en lang række psykiske reaktioner. Disse omfatter frygt, vrede og regression (Dowdney, 2000; Holland, 2008) søvnløshed, påtrængende tanker, apati og psykosomatiske symptomer (Bylund-Grenklo, Fürst, Nyberg, Steineck, \& Kreicbergs, 2016; A. Dyregrov, 2008; Parkes \& Weiss, 1983), og udviklingen af skizofreni (Liang et al., 2016). Flere forskere (fx Akerman \& Statham, 2014; Auman, 2007) har yderligere identificeret skyldfølelse som en ofte overset, men tilstedeværende risikofaktor, der kan være svær at anerkende og håndtere for de sorgramte 
børn. Niveauet af skyldfølelse synes medieret af, hvordan den tilbageværende forælder håndterer dødsfaldet.

I dag er risikoen for depression dog mest veldokumenteret (fx Brent, Melhem, Donohoe, \& Walker, 2009a; Dowdney, 2000). Selvom majoriteten af forskning peger på en direkte forbindelse imellem tabet af en forælder som barn og risikoen for at pådrage sig klinisk depression, så er forskere uenige om størrelsen af denne risiko. I en undersøgelse fra Gersten, Beals og Kallgren (1991), som inkluderede 92 børn i alderen 8-15 år, fandt forskerne, at 10\% af deres deltagere opfyldte kriterierne for svær klinisk depression. Studiet led dog af den svaghed, at det ikke inkluderede tidsperioden for, hvornår deltagerne havde mistet, som en faktor. Det er derfor svært at vide, om depressionen kun var noget, der eksisterede i perioden lige efter tabet, eller om det var en vedblivende faktor.

Den svaghed undgik Gray, Weller, Fristad og Weller (2011), da de interviewede 325 børn to måneder efter deres tab. De fandt, at $24 \%$ af deres deltagere havde haft episoder med svær depression. I en skandinavisk kontekst opdagede Berg, Rostila og Hjern (2016) en lille stigning i risiko for depression blandt unge, der havde mistet en forældre grundet naturlige årsager. Denne risiko var højere ved pludselige dødsfald, og især hvis børnene havde mistet i en ung alder. Forskerne antog yderligere, at særligt ved pludselige dødsfald, såsom selvmordsforsøg, kunne dette skyldes psykosociale faktorer i familien, som barnet kunne arve. Samtidigt påpegede Berg, Rostila og Hjern (2016) at pludselige dødsfald ofte var mere udfordrende og belastende for familiens sociale netværk, og at dette kunne svække dets naturlige evne til at støtte barnet. Det bør dog her påpeges, at der stadig kun er få, der har været indlagt (3-4\% efter pludselig død) og relativt få, der havde modtaget ambulant behandling (ca. 10\%) (Berg et al., 2016).

At depressive symptomer kunne være vedvarende, satte Grenklo, Fürst, Nyberg, Steineck og Kreicbergs (2016) fokus på i et skandinavisk studium baseret på et spørgeskema med 622 respondenter, der alle havde mistet en far eller mor i alderen 13-16 år. Forskerne fandt, at 6-9 år efter tabet rapporterede $49 \%$ af respondenterne, at de havde fået lidt eller ingen forløsning på deres sorg, og studiet viste, at gruppen stadig kæmpede med søvnløshed, træthed og moderat til svær depression. Det er dog her værd at bemærke, at »resolution« blev vurderet gennem et enkelt spørgsmål, hvor forfatterne spurgte: »har du arbejdet dig igennem din sorg?»

I et longitudinelt befolkningsbaseret studium af Brent et al. (2009b) viste det sig, at der, 2 år efter at unge havde mistet en forælder, eksisterede en højere forekomst af depression, angst og funktionsudfald, sammenlignet med kontrolgruppen af 
unge, der ikke har mistet. Forekomsten af depression 21 måneder efter tabet var således størst ved selvmord og tabet af en mor, mens forekomsten for depression lige efter dødsfaldet var størst efter dødsfald relateret til selvmord. Selv om reaktionerne aftog over tid for de fleste mennesker, fandt forskningsgruppen, at omkring 10\% ikke viste tegn på ændringer selv 33 måneder efter dødsfaldet (Brent et al., 2009b).

\section{Risiko for psykiske lidelser senere i livet}

Flere undersøgelser (Agid et al., 1999; f. eks. Appel et al., 2016; Hayslip, Pruett, \& Caballero, 2015) har beskrevet, hvorledes tab i barndommen er forbundet med forøget risiko for udviklingen af psykiske lidelser (klinisk depression, bipolar lidelse, skizofreni, angst) i voksenlivet. Forskere (fx Grassi-Oliveira, Honeycutt, Holland, Ganguly, \& Brenhouse, 2016; Ishikawa, Nishimura, \& Ishikawa, 2015) har dog generelt set i højere grad været optaget af at undersøge sådanne udfordringer i forhold til generelle stressfaktorer i børns liv frem for som specifik konsekvens af forældretab.

Blandt de undersøgelser (fx Dowdney, 2000; Melhem, Walker, Moritz, \& Brent, 2008), der har udforsket konsekvensen for psykisk sygdom ved forældretab, er der blevet fundet en sammenhæng mellem sådanne dødsfald og en øget risiko for posttraumatisk stress-syndrom (PTSD) i voksenlivet. Her fandt Melham et al. (2008), at børn og unge $(n=140)$, der mistede en forælder i alderen 7-25 år, havde en 8,5 procentpoint højere risiko for at udvikle PTSD sammenlignet med undersøgelsens kontrolgruppe ( $\mathrm{n}=99$ ). Denne risiko steg yderligere i tilfælde, hvor der var traumatiske (fx selvmord, bilulykke, mord) elementer i dødsfaldet.

I et landsdækkende kohortestudium baseret på danskere $(n=1.124 .215)$ født mellem 1970 og 1990 undersøgte Appel et al. (2016) forbindelsen mellem tabet af en forælder i barndommen og brugen af antidepressiv medicin i voksenlivet. Studiet fandt, at 9.608 deltagere havde mistet i alderen 6-19 år, og at denne gruppe havde et signifikant større forbrug af antidepressive lægemidler. Jo yngre barnet var på tabstidspunktet, jo større var dette forbrug. Appel et al. (2016) registrerede yderligere, at dette forbrug ikke var formindsket to år efter dødsfaldet.

Afslutningsvis er det værd at bemærke, at hvis man ser bort fra arbejdet med udviklingen af en sorgdiagnose (fx Bryant, 2014; Lundorff, Holmgren, Zachariae, Farver-Vestergaard, \& O'Connor, 2017), så er der igennem de seneste år kun blevet foretaget meget få studier, der har evalueret risikoen for at udvikle psykiske sygdomme som konsekvens af et forældretab. Dog har studier (fx Greeson et al., 2014; 
Koenen, Moffitt, Poulton, Martin, \& Caspi, 2007), der mere generelt undersøgte sammenhængen mellem tidlige stressfaktorer ( $f x$ fysisk og psykisk misbrug, forsømmelse) i livet og udviklingen af psykiske lidelser, fundet en overordnet sammenhæng mellem disse erfaringer og udviklingen af psykisk sygdom.

\section{Sociale konsekvenser}

Der eksisterer i dag relativt lidt viden om de sociale konsekvenser, der opstår, når børn mister en forælder. Flere undersøgelser (fx Cerel, Fristad, Verducci, Weller, \& Weller, 2006; Dopp \& Cain, 2012) har dog rapporteret, at de udfordringer, der opstår efter tabet af en forælder, virker til at kunne skabe lige så store problemer som dødsfaldet selv. Forskere (fx Balk, 2010; A. Dyregrov \& Dyregrov, 2008) har her påvist vigtigheden af, at børnenes venner støtter op i tiden efter tabet. Dette virker til at blive vigtigere, jo ældre barnet er.

I dette perspektiv er det problematisk, at Holland (2001) og Lytje (2016) har fundet, at dødsfald i familien på sigt kan føre til tab af venner, hjem, skoler, fællesskaber og stabilitet. Cerel et al. (2006) har ligeledes beskrevet, hvordan socioøkonomisk status og niveauet af depressiv adfærd udvist af den tilbageværende forælder direkte kan influere på barnets resiliens. Andre studier (Brent et al., 2009; Mack, 2001; Melhem, 2008) har fundet, at dødsfaldet kan lede til tab af selvtillid og øge risikobetonet adfærd såsom at komme i slåskampe, køre uden sikkerhedssele og engagement i risikabel seksuel adfærd. Disse udfordringer er yderligere beskrevet $\mathrm{i}$ afsnittet omkring risikobetonet adfærd.

Tab af venner blev af Lytje (2016) foreslået at opstå, fordi både den sorgramte elev og klassekammeraterne havde svært ved at finde ud af, hvordan de skulle opsætte rammer for den svære samtale om tabet. K. Dyregrov \& Dyregrov (2005) fandt ligeledes, at børn, der havde mistet en søskende til selvmord, ofte beskrev deres venner fra før tabet som "barnlige, umodne og fokuseret på irrelevante og meningsløse ting « (s. 720). Selvom dette fund ikke kan overføres direkte til forældretab, giver det en indikation om, at der ofte følger sociale udfordringer med tabet af et nært familiemedlem. I en anden undersøgelse omkring børn og unge som pårørende til afdøde forældre med kræft beskrev K. Dyregrov og Dyregrov (2011) ligeledes, at oplevelsen ofte fik børnene til at føle, at de havde et mindre tilhørsforhold til deres jævnaldrende end før. En række af børnene oplevede yderligere en frygt for at omgås mennesker i almindelighed. Tabet havde gjort dem usikre i forhold til at skabe interpersonelle relationer og bange for at indgå i forpligtende forhold af frygt for at miste disse igen. 
Høeg et al. (2018) fandt i dette perspektiv, at børn, der har mistet en forælder, som voksne yderligere risikerer at opleve udfordringer i forhold til parforhold. Igennem registerdata for alle danske børn født i 1970 og 1995 ( $\mathrm{N}=1.525 .173)$, som havde mistet en forælder, før de blev atten år, viste undersøgelsen, at forældertab var forbundet med en højere relationsdannelse for unge kvinder, men ikke for unge mænd, såvel som højere separationsrate for både mænd og kvinder. Høeg et al. (2018) fandt også, at denne risiko var højere for individer, som havde mistet en forælder til selvmord.

Når man ser på de sociale konsekvenser af dødsfald i familien, spiller miljøet, hvor barnet bor, ligeledes en væsentlig rolle. At miste en forsørger kan i nogle dele af verden have katastrofale konsekvenser. Her kan tabet betyde, at familien måske ikke længere har råd til at leve, hvor den gør, ikke kan betale for skolen og aldrig får tilbud om ekstern støtte (Holland, 2001; Mallon, 2010). En sådan situation er mindre sandsynlig i Norden, hvor det socialpolitiske system er veletableret, og de fleste mennesker har livsforsikringer. Under sådanne omstændigheder kan et barn stadig ende med at skulle skifte skole eller hjem, men der er langt mindre risiko for, at familien lider så voldsomt et økonomisk sammenbrud, at økonomi falder helt fra hinanden.

\section{Reduceret livsglæde}

Det har været en udfordring for forskere at afdække de langsigtede konsekvenser af tab i barndommen. Det skyldes delvist vanskelighederne $i$ at isolere konsekvenserne af et dødsfald fra andre livsfaktorer (fx pubertet, socioøkonomiske faktorer), som også spiller ind på børnenes udvikling igennem barndommen. I dette perspektiv har Parsons (2011) dog lavet et interessant studium i England, hvor hun undersøgte de fysiske og psykiske konsekvenser ved tab i barndommen for 534 voksne. Igennem en sammenligning af forskellene på, hvordan disse klarede sig i forhold til ikke-sorgramte børn, afdækkede hun flere forskelle. Studiet viste, at de sorgramte som 30-årige havde en forøget risiko for ikke at have et arbejde. Derudover var de sorgramte voksne yderligere mere tilbøjelige til at rapportere, at de »aldrig fik det ud af livet, de havde håbet på«(Parsons, 2011, s. 11). Et stort studie foretaget af Moor \& Graaf (2016), som gjorde brug af en randomiseret stikprøve på 1500 mennesker fra 47 lande (n=70.500), fandt ligeledes signifikante forskelle på oplevelsen af glæde i livet, når man var sorgramt. Både i tiden lige efter og ti år senere var mennesker, der havde mistet en forælder som barn, mindre glade end mennesker, der ikke havde. Da Parsons (2011) kontrollerede sine data for sociale 
karakteristikker og familiekarakteristikker, kunne betydningen af at være fra en sorgramt familie dog ikke bekræftes inden for det relevante statistiske signifikansniveau. Det havde den konsekvens, at de oplevede udfordringer lige så vel kunne være forårsaget af udfordringer i familien under opvæksten, som være en konsekvens af tabet.

\section{Social isolation og mangel på medbestemmelse $i$ skolen}

I et kvalitativt studium af Lytje (2016a) om omkring 39 sorgramte danske børns oplevelser med at vende tilbage til skolen efter tabet af en forælder blev det beskrevet, hvordan de sorgramte børn sjældent var forberedte på mængden af de udfordringer, der opstod i skolen, når de vendte tilbage. Det var her ikke unormalt at vende tilbage til en klasse og nogle venner, der ikke rigtigt vidste, hvordan man skulle tale om, hvad der var sket. Som konsekvens talte man ofte ikke om dødsfaldet, og det fik børnene til at føle sig anderledes og alene med deres sorg. På samme tid følte børnene sjældent, at de havde medbestemmelse over, hvad der skulle ske på skolen i forbindelse med deres sorg. De beskrev det som ubehageligt, når de ikke fik muligheden for at sige fra over for tiltag såsom at skulle deltage $\mathrm{i}$ fællessang eller gå til skolepsykolog. Eleverne ønskede derfor at blive inkluderet i processen omkring, hvordan deres skole håndterede sorgen. Det blev ligeledes oplevet som et problem, at skolerne ofte glemte børnenes sorg, som tiden gik. Det kunne føre til episoder, hvor lærere tog døden op som emne uden at varsle den sorgramte elev. Sådanne episoder blev af børn beskrevet som "et helvede" og var med til at gøre det svært for eleverne at trives og præstere. Studier, der spørger ind til børnenes ønsker til støtte, er sjældne, men i et af de få, der eksisterer, fandt K. Dyregrov (2009) lignende tendenser, da hun interviewede 32 norske børn, som havde oplevet selvmord i den nærmeste familie. Den største forskel imellem de to studier var, at hvor Dyregrovs (2009) deltagere generelt ikke syntes, de fik nok hjælp, så var de danske børn (Lytje, 2016b) mere positivt stillede over for den hjælp, de modtog i skolen. Denne forskel i svar kan dog muligvis tilskrives, at Dyregrov (2009) specifikt forholdt sig til selvmord, som er mere tabubelagt end mange andre dødsfaldstyper (Diekstra \& Hawton, 2012).

\section{Risikobetonet adfard}

Det er ikke kun økonomien, der ændrer sig i tiden efter et tab. Der findes i dag også evidens for, at sorgramte børn har en forhøjet risiko for at deltage i risikobe- 
tonet adfærd. Flere forskere (fx Cross \& Harrison, 2002; Dennehy, 1966; Worden, 1996) har påvist en sammenhæng mellem tab af en forælder og risikobetonet adfærd. Blandt andet beskrev et til en vis grad overset dansk studium af Nielsen, Sørensen og Hansen (2012), som inkluderede 3.481 respondenter i alderen 15-24 år, en sammenhæng mellem det at have et svagt socialt netværk og denne form for adfærd. Forskerne fandt, at sorgramte børn havde en større sandsynlighed for at være rygere, have prøvet euforiserende stoffer og have begået kriminalitet. $36 \%$ af de sorgramte børn rapporterede, at de røg regelmæssigt i forhold til 19\% af deres ligesindede. 52\% af de sorgramte børn havde erfaringer med euforiserende rusmidler sammenlignet med 35\% af deres ligesindede. Denne tendens blev bekræftet $\mathrm{i}$ et dansk kohortestudium (Høeg et al., 2016), som inkluderede 1.796 voksne, der havde mistet en forælder som barn. Her fandt man en signifikant forøgelse i brugen af rusmidler i forhold til den ikke-sorgramte kontrolgruppe. Samme resultater blev fundet af Hamdan et al. (2012), som fandt, at forældretab var direkte forbundet med det, der kaldes sundhedsrisikoadfærd (at deltage i risikable aktiviteter, tage risici, vilde fester $\mathrm{mm}$.).

I tiden efter tabet kan mobning også spille ind som en risikofaktor for trivslen i skolen. I denne forbindelse fandt det tidligere nævnte danske studie, Nielsen et al. (2012), en association imellem tab og mobning. Nielsen et al. (2012) rapporterede, at $54 \%$ af de sorgramte børn havde oplevelser med at blive mobbet, mens $51 \%$ selv havde været med til at mobbe andre. Dette tal var yderligere negativt korreleret med børnenes adgang til en støttende ven eller en voksen.

I sin videre analyse af konsekvenserne ved tab af en forælder fandt Nielsen et al. (2012) derudover, at 35\% af de sorgramte deltagere havde begået kriminelle handlinger såsom overfald eller tyveri. Det var 7\% højere end i prøven for de ikkeefterladte. Udover mobning var børnenes erfaringer med at begå fysiske overgreb negativt korreleret med, om barnet havde nogen at tale med. Et andet foruroligende fund gjort af Nielsen et al. (2012) var, at risikoen for at have været offer for incest var fem gange højere for sorgramte piger end deres ligesindede. En af de vigtigste konklusioner, der kan udledes fra Nielsen et al. (2012), er vigtigheden af, at børn og unge har nogen at tale med i tiden efter et tab. Det er som beskrevet direkte korreleret med flere alvorlige konsekvenser. I den forbindelse fandt studiet, at $20 \%$ af deres deltagere rapporterede, at de ikke havde nogen at tale med om deres tab. 


\section{Opsummering}

De meget divergerende fund viser en del inkonsistens i resultaterne relateret til tabets konsekvenser i forskningsverdenen. Mens en overvægt af studier viser, at mange udfordringer ved tabet af en forælder er vedvarende, viser en mindre række studier, at de sørgende opnår en hel eller delvis resolution på deres sorg i årene efter tabet. Disse forskellige resultater kan være et udtryk for, hvorledes den måde de sørgende vælger at håndtere tabet på, spiller ind på sorgens forløb. Både Currier, Neimeyer og Berman (2008) samt Bylund-Grenklo, Fürst, Nyberg, Steineck og Kreicbergs (2016) fandt således en association mellem det at sørge tidligt (før eller lige efter dødsfaldet) og at komme sig. På samme tid spekulerede Byland-Grenklo et al. (2016) i, om den store mængde af unge, der kun fik ringe resolution, skyldtes en mangel på overskud i en tid, hvor børnene skulle forholde sig til et eventuelt sygdomsforløb og den tilbageværende families smerte. Selvom der således findes en lang række studier på området, der undersøger sørgendes evne til at få resolution, så er der i høj grad også behov for flere studier, der ser nærmere på de faktorer, der spiller ind på muligheden og tidspunktet for denne.

\section{Fysiske reaktioner og helbredsmæssige risici}

En række studier har formået at påvise en relation mellem tab i barndommen og forhøjede risici for at opleve fysiske reaktioner i tiden efter et tab, forøgede risici for sygdom samt forhøjet dødelighed. Samtidigt er der fundet en forbindelse mellem forældretab og selvmord. Disse udfordringer ser vi nærmere på i dette afsnit.

\section{Fysiske reaktioner}

Forskere (fx. Nielsen et al., 2012; Stroebe, Schut, \& Stroebe, 2007) har identificeret en forøget forekomst af fysiske helbredsproblemer blandt sorgramte børn. Disse reaktioner indbefatter hovedpine, søvnløshed, svimmelhed, tab af appetit, koncentrationsbesvær og brystsmerter. I et større perspektiv har meget få forskere dog interesseret sig for at udforske de fysiske symptomer, der kan opstå hos børn efter tabet af en forælder.

Det er dog værd at bemærke, at Luecken (2008) i en litteraturgennemgang af konsekvenserne af børns tab fandt, at mange af de fysiske problemer, børnene oplevede, viste sig at være livslange frem for midlertidige. Dette fund er senere 
blevet nuanceret i den tidligere nævnte undersøgelse af Bylund-Grenklo et al. (2016), som undersøgte konsekvensen af at have mistet en forælder i alderen 1316 år igennem et spørgeskema til deltagere $(n=622))$, der nu var mellem 18-26 år gamle. I studiet rapporterede $49 \%$ af respondenterne, at de ikke havde fået resolution på deres sorg 6-9 år efter tabet af en forælder. De led yderligere stadigvæk af symptomer såsom søvnløshed, vedvarende følelser af træthed, moderat til svær depression såvel som påtrængende tanker. I 2002 foretog Neeleman, Sytema og Wadsworth en stor kohorteundersøgelse af 5.362 midaldrende deltagere. Her fandt forskerne, at deltagere, der havde mistet en forælder, før de blev 16 år, rapporterede flere helbredsproblemer end deres ikke-sorgramte ligesindede. Andre studier (e.g. Agid et al., 1999; Krause, 1998) har ligeledes bekræftet denne tendens, og har alle kunnet kæde forældretabet sammen med en livslang stigning i helbredsmæssige problemer.

Det bør dog noteres, at ikke alle forskere er enige om eksistensen af denne risiko. En række andre studier (e.g. Clark, Caldwell, Power, \& Stansfeld, 2010; Otowa, York, Gardner, Kendler, \& Hettema, 2014), som også undersøgte de livslange konsekvenser, formåede ikke at finde nogle signifikante associeringer imellem tabet af en forælder og forøgede helbredsproblemer senere i livet. Disse forskelligrettede resultater giver umiddelbart et lidt usikkert billede af niveauet af langsigtede fysiske reaktioner efter et forældretab. I en af de nyeste litteraturgennemgange af emnet fremførte Luecken (2012) dog, at en lille majoritet af studier synes at have fundet evidens for, at tab af en forælder kan associeres med forskellige fysiske udfordringer senere i livet. Sådan risiko forøges yderligere, når tabet af en forælder skyldes selvmord, ulykker og uventede dødsfald (Luecken, 2008).

Stroebe, Schut og Stroebe (2007) cementerer ligeledes i The Lancet det problematiske i, at forskere ikke har interesseret sig for de fysiske symptomer, som børn oplever i tiden efter tabet. Forskerne argumenterer for, at området generelt er for lavt prioriteret, og at der inden for feltet eksisterer en tendens til at undervurdere, hvor vigtig en rolle dødsårsagen og den sørgendes personlighed spiller for sorgreaktionens form og styrke. Stroebe, Schut, og Stroebe (2007) konkluderer yderligere, at den eksisterende evidens indikerer, at mennesker, der har mistet en nærtstående, generelt har forøget risiko for at få helbredsmæssige udfordringer, særligt i tiden lige efter et tab. Det må dog konstateres, at selvom der i dag eksisterer en relativt bred viden omkring de mentale udfordringer, der følger tabet af en forælder, så ved forskere meget lidt om de fysiske konsekvenser, der følger af disse tab. 


\section{Helbredskonsekvenser}

Studier om helbredsmæssige udfordringer relateret til tabet af en forælder har generelt været meget sjældne. Et studium, (Kravdal \& Grundy, 2016), som dog inkluderede unge voksne, undersøgte konsekvenserne af et forældretab for mennesker i alderen 18-59 år i den samlede norske befolkning. Forskerne fandt her, at deltagernes fysiske helbred blev forværret direkte efter tabet og forblev dårligt på længere sigt. Denne udvikling kunne spores igennem forøget brug af medicin hos de sorgramte. Effekten var dog svag, og stigningen i medicin var ikke højere end $1-7 \%$. Interessant nok fandt studiet ligeledes, at mens forbruget af medicin forbundet med psykiske problemer på sigt blev mindsket, så var det modsatte tilfældet for medicin associeret med fysiske udfordringer. Selvom det er interessant, er det svært at vide, om de samme tendenser kan overføres til børn, der har mistet, før de blev 18 år. I det tidligere nævnte studium af Parsons (2011) fandt forskeren, at de kvindelige deltagere generelt rapporterede at have et dårligt eller gennemsnitligt, men ikke fantastisk helbred. Samtidigt rapporterede $6 \%$ af mændene, at de var på førtidspension. Selvom dette tal ikke er højt, var det en fordobling i forhold til børn, der var vokset op i familier med to forældre.

\section{Forhøjet dødelighed}

Forskere (fx Rostila \& Saarela, 2011; Smith, Hanson, Norton, Hollingshaus, \& Mineau, 2014) har yderligere vist, at tab i barndommen har en direkte indvirkning på de sorgramtes generelle dødelighed (sygdomsrelaterede dødsfald, ulykker og selvmord). Li et al. (2014) inkluderede alle statsborgere født i Danmark imellem 1968 og 2008 ( $n=2.789 .807$ ) og i Sverige fra 1973-2006 ( $n=3.380 .301)$, såvel som en randomiseret stikprøve of 90\% af alle mennesker født i Finland fra 1987 til 2007 ( $n=1.131 .905$ ). Blandt disse grupper var der 189.094 personer, som havde mistet en forælder, før de fyldte 18 år. Gennem brug af log-lineær Poisson-regression fandt Li et al. (2014), at tab af en forælder i barndommen var forbundet med, at de sorgramte børn oplevede en 50\% forøgelse i risiko for at dø før tid. Hvis forældrenes dødsfald skete af unaturlige årsager (f.eks. selvmord, bilulykker), steg dødeligheden yderligere. Disse resultater var uanset køn og alder på tidspunktet for dødsfald og efter at have taget forbehold for grundkarakteristika såsom socio$ø$ konomisk status. Mens undersøgelsen kunne forudsige stigningen i dødelighed, formåede resultaterne ikke at vise, i hvilket omfang dette påvirkede de sorgramtes liv. Studiet forudså kun stigningen i dødsfald, og ikke om disse sker en dag eller 
år før. Undersøgelsen fandt dog yderligere, at den kortsigtede risiko synes at variere alt efter barnets alder ved dødsfaldet. Her var dødeligheden negativt associeret med barnets alder. Jo yngre et barn var ved tabet, jo højere var risikoen. Li et al. (2014) argumenterede for, at det kunne indikere en mangel på pleje umiddelbart efter dødsfaldet, som var særligt problematisk for de helt små børn. Den overordnede og generelle forøgelse af risiko forblev dog høj i mere end 20 år, uanset det sorgramte barns alder.

De ovenstående fund er støttet af en tidligere undersøgelse foretaget af Rostila og Saarela (2011). Forskerne brugte en registerdatabase, som indeholdt den samlede svenske befolkning, og fandt lignende resultater. De opdagede yderligere, at en mors død syntes at have en større indflydelse end tabet af en far. Drengebørn synes derudover at være mere sårbare end piger. Selvom begge undersøgelser havde imponerende stikprøvestørrelser, led de dog af de samme begrænsninger. Den største begrænsning var manglen på oplysninger omkring livsstil samt deltagernes socioøkonomiske forhold. Selvom studierne således fandt en sammenhæng mellem tab af en forælder og dødelighed, formåede de ikke at identificere de bagvedliggende grunde.

En undersøgelse, der tog forbehold for sådanne betingelser, blev foretaget af Smith et al. (2014). Forskerne undersøgte her risikoen for en vedvarende forhøjet dødelighed efter tabet af en forælder for mennesker over 65 år. Data blev udtrukket fra the Utah Population Database (92.618). Undersøgelsen fandt, at børn (og især unge/unge voksne), hvis forældre døde, i starten havde en begrænset stigning i dødelighed, som dog steg signifikant, efter at de fyldte 65 år. Disse risici var kun svagt associeret med komorbiditet, ægtestand, fertilitet og den voksnes socioøkonomiske status. Derudover ændrede dødelighedsprognoserne sig ikke signifikant, når de blev kontrolleret for de ovenstående faktorer.

\section{Selvmordsrisiko}

To større studier har fundet en association mellem tab af en forælder og risikoen for selvmordstanker og selvmordsforsøg blandt sorgramte børn. Dette inkluderer den føromtalte undersøgelse af Nielsen et al. (2012). Rapporten fandt, at $24 \%$ af de sorgramte børn rapporterede at have haft selvmordstanker, mens $8 \%$ havde forsøgt at tage deres eget liv. Denne tragiske tendens blev bekræftet i et stort svensk kohortestudium (Rostila, Berg, Arat, Vinnerljung, \& Hjern, 2016) af statsborgere $(\mathrm{n}=871.402)$ født imellem 1973-1982. Studiet fandt en direkte association med tabet af en forælder og risikoen for at have forsøget at tage sit eget liv. Denne risiko var 
højest, når forælderen var død af unaturlige årsager (fx stofmisbrug, selvmord), men også forøget ved naturlige dødsfald. Risikoen var stadig til stede, efter at studiet havde justeret for socio-demografiske faktorer.

Flere studier har vist, hvorledes risikoen for, at børn begår selvmord, drastisk forøges, hvis deres forældre selv døde af denne årsag. Guldin et al. (2015) har i dette perspektiv foretaget et registerbaseret studium, hvor 7 millioner mennesker fra Danmark, Sverige og Finland indgik. Studiet viste, at omkring 190.000 børn i perioden mellem 1968 og 2008 mistede en forælder, før de blev 18 år gamle. Det gjaldt for alle børnene, der har mistet forældre - uanset årsag - at risikoen for selvmord var fordoblet sammenlignet med dem, der ikke havde mistet. For dem, der selv havde mistet ved selvmord var risikoen mere end tredobbelt. Studiet viste ligeledes, at børn, der havde mistet ved selvmord, havde $82 \%$ højere risiko at tage deres liv i forhold til børn, der havde mistet en forældre i en ulykke. I årsagerne hertil peger Guldin et al. (2015) på fælles genetisk disposition, miljøfaktorer, sociale ændringer og psykologisk stress som de mulige kausale forklaringer. Selvom tallene for selvmord er høje, bør det dog her understreges, at det overordnet set er meget få af dem, der har mistet en forælder $(0,14 \%)$, der tager deres eget liv (Guldin et al., 2015).

De ovenstående fund er bekræftet i både internationale og nordiske studier. Et taiwansk registerstudium (Lee, Li, Chang, Lu, \& Chen, 2017) undersøgte børns forøgede risiko for selv at begå selvmord ved tab af en mor $(n=14,431)$, far ( $n=$ $26,887)$ eller begge forældre $(n=281)$ i familien. Studiet fandt, at børn, der havde oplevet, at en forælder begik selvmord, selv havde næsten fire gange så høj risiko for at dø af denne årsag. Risikoen var formindsket blandt ældre drengebørn, men forøget blandt ældre piger. I det tidligere nævnte svenske studium af Niederkrotenthaler et al. (2012), fandt forskerne, at der eksisterede en tredobling i risikoen for, at børnene begik selvmord, hvis forældrene havde taget deres eget liv. Denne risiko var større for dem, der havde mistet i en meget ung alder. Yderligere fandt en stor undersøgelse af Mittendorfer-Rutz (2008), som omfattede 14.440 deltagere, der havde prøvet på at tage deres eget liv, såvel som en kontrolgruppe på 144.400, at $20 \%$ af selvmordsforsøgene kunne tilskrives tidligere selvmord eller selvmordsforsøg i familien.

Selvom der således eksisterer evidens for den forøgede dødelighed, har flere studier også fundet, at socioøkonomiske omstændigheder i familien (fx Burrell, Mehlum, \& Qin, 2017; Mackenbach et al., 2008) samt adfærdsændringer (fx Brent et al., 2009; Melhem, 2008) synes at være lige så vigtige indikatorer i estimeringen af risikofaktorer. Berg et al. $(2016 ; 2014)$ fandt her, at eksterne faktorer såsom den 
overlevende forældres mentale helbred, evt. alkohol- og stofmisbrug såvel som fattigdom var stærke indikatorer for selvmord. Derfor konkluderer Berg et al. (2014), at selvom denne risiko muligvis ændrer sig, efter mennesker fylder 65 år, så viser majoriteten af nuværende studier (e.g. Brent et al., 2009; Parsons, 2011), at de observerede konsekvenser hos sorgramte ofte så ud til at skyldes socioøkonomiske forhold, som allerede var til stede i familien før dødsfaldet.

Flere litteraturgennemgange (fx Baldessarini \& Hennen, 2004; Bondy, Buettner \& Zill, 2006) har ligeledes påvist, at der muligvis kan være en genetisk komponent involveret i selvmordsrisici. Baldessarini og Hennen (2004) beskriver her, hvordan forskere (fx Mann, Brent, \& Arango, 2001; McGuffin, Marušič \& Farmer, 2001) har kunnet spore en signifikant højere risiko for selvmord blandt efterladte, der er biologisk relateret til et selvmordsoffer frem for adopteret. De komplekse forhold mellem miljøskabte og biologiske stressfaktorer gør det dog svært at definere, præcist hvor stor en rolle gener spiller.

\section{Uddannelsesmæssige konsekvenser}

Forskning har vist, at tabet af en forælder har store konsekvenser for børns skolegang. Tabet komplicerer ofte både relationer til venner, selvbilleder og koncentrations- og præstationsevner. Samtidigt har flere studier vist, at unge, der mister en forælder, som voksne sjældent har de samme karrieremæssige aspirationer som deres ligesindede. Disse emner udforsker vi i dette afsnit.

\section{Koncentrations- og præstationsbesvær}

Igennem de sidste to årtier har flere studier også undersøgt, hvordan tabet af en forælder påvirker barnets koncentrations- og præstationsevne i skolesystemet, ofte med divergerende og inkonsistente fund som resultat. En række forskere (fx. Abdelnoor \& Hollins, 2004; Berg et al., 2014) har foretaget studier, der har fundet, at sorgramte børn har forøget risiko for at underpræstere i skolen i forhold til deres jævnaldrende. Andre studier (fx Dowdney, 2000; Silverman \& Worden, 1993) har fundet, at nogle sorgramte børn præsterer bedre i tiden efter tabet. I sin gennemgang af studierne fremhæver Dowdney (2000), at de divergerende resultater kan skyldes inkonsistens i studiernes metodologi. Mange af undersøgelserne tog ikke faktorer som tidligere skolepræstation, barnets generelle kompetenceniveau og typen af tab i betragtning. Dowdney (2000) pointerer ligeledes, at den øgede 
præstationsevne muligvis kan tilskrives, at barnet arbejder så hårdt, det kan, i et forsøg på at ære den afdødes minde. En anden forklaring kan være, at det sorgramte barn bruger sin energi på at koncentrere sig om skolearbejdet som en form for forsvarsmekanisme.

Det er lige så svært at præcisere de bagvedlæggende grunde til de negative præstationer i skolen, som det er at forklare de positive præstationsforøgelser. Holland (2008) forklarer, at reaktioner kan variere fra barn til barn afhængigt af alder, erfaringer, personlighed og form af tab. Dowdney (2000) hævder, at det gør det vanskeligt at foretage nogen form for generel konklusion om konsekvenserne af børns tab, andet end at de varierer. Denne konklusion er nu 17 år gammel, og siden da har både danske (Høeg, Johansen, Christensen, Frederiksen, Dalton, Bøge et al., 2018; Nielsen et al., 2012) og internationale undersøgelser (fx. Abdelnoor \& Hollins, 2004; A. Dyregrov, Dyregrov, Endsjø \& Idsoe, 2015) fundet, at mange af de sorgramte børn, der har mistet en forælder, har en forøget risiko for at underpræstere i skolen.

En af de hyppigst rapporterede problemer, der hæmmer børnenes evne til at præstere i tiden efter et tab, er koncentrationsproblemer. Denne udfordring er blevet dokumenteret igennem interviews både med børnene selv (fx. Lytje, 2016b; Silverman \& William, 1992) og deres lærere (fx Dowdney et al., 1999; A. Dyregrov et al., 2015). Ifølge K. Dyregrov (2004) kan problemet ofte tilskrives, at det sørgende barn oplever påtrængende minder om den afdøde forælder, når det forsøger at koncentrere sig, særligt når der er traumatiske elementer tilknyttet dødsfaldet. Det er især et problem i undervisning, der kræver en høj grad af opmærksomhed. Desuden kan både psykologiske og sociale problemer såsom depression og fald i familiens indkomst føre til ændringer i livssituationen, der påvirker barnets evne til at fungere i skolen (Cerel et al., 2006). Der eksisterer ligeledes andre faktorer såsom regressiv adfærd, øget fravær fra skolen og reduceret selvværd, der kan påvirke præstationsevnen (A. Dyregrov et al., 2015; Holland, 2008). I en gennemgang af området konkluderede A. Dyregrov (2004) dog, at selvom vi i dag har en bred forståelse af, at tab kan lede til indlæringsudfordringer, så har vi langt mindre viden om hvorfor. Han problematiserede yderligere det faktum, at der ofte findes særudviklede støttetiltag til unge med indlæringsudfordringer, men ikke til børn med sorg. 


\section{Uddannelsesmæssige aspirationer og uddannelsesniveau}

To undersøgelser (Brent, Melhem, Masten, Porta, \& Payne, 2012; K. Dyregrov, 2004) fandt yderligere, at sorgramte børn havde lavere uddannelsesmæssige aspirationer og færre planer for deres egen karriereudvikling. Gerard og Buehler (2004) beskrev dog, at hvis eleven tidligere havde haft et højt fagligt niveau og positivt selvværd, så kunne disse faktorer kompensere for nogle af de ovenstående risici. Resiliensfaktorerne tilbød dog kun en begrænset beskyttelse og kunne overtrumfes, når andre risikofaktorer (fx problemer i hjemmet eller med klassekammerater) var til stede i mere end ét domæne af børnenes liv.

I det tidligere nævnte studium af Parsons (2011) blev det ligeledes demonstreret, hvorledes børn fra familier med tab som 16-årige havde flere udfordringer med at præstere i skolen og færre ambitioner for fremtiden end deres ikke-sorgramte klassekammerater. Der var ligeledes også evidens for, at de i højere grad havde pjækket fra skole og oplevet at blive suspenderet. Selvom denne risiko gjaldt for begge køn, var drenge særligt udsatte. Samtidigt fandt studiet, at sorgramte børn, når de nåede 30-års alderen, havde en højere risiko for at være arbejdsløse.

På samme måde fandt Berg et al. (2014) igennem en register-baseret national kohorteundersøgelse af 772.117 deltagere født i Sverige mellem 1973 og 1981 en sammenhæng mellem dødsfald i barndommen og risikoen for at klare sig dårligt i uddannelsessystemet. Da dataene blev kontrolleret for udsving skabt på baggrund af sociale karakteristika og familiekarakteristika, viste det sig, at de i højere grad var ansvarlige for den dårlige skolepræstation end selve tabet. Det fik Berg et al. (2014) til at konkludere, at baseret på den nuværende tilgængelige evidens (fx Brent, Melhem, Donohoe, \& Walker, 2009; Parsons, 2011), så synes negative langsigtede konsekvenser af tab I familien i højere grad at skyldes familiekarakteristika (fx socioøkonomiske ressourcer, familiens netværk), der allerede var til stede før dødsfaldet.

Et andet studium af Prix og Erola (2017) baseret på børn født mellem 1982 og 1987, der mistede en far, fandt derudover, at deltagerne ikke droppede ud af deres videregående uddannelse (gymnasium), så længe mødrene havde stærke socioøkonomiske ressourcer. Dog klarede de unge sig dårligere på universitetet i forhold til de studerende, der ikke havde mistet. Forfatterne konkluderede derfor, at når unge blev ramt af dødsfald, så ville de, der hørte til gruppen med stærke socioøkonomiske ressourcer, have nemmere ved at afbøde potentielle negative konsekvenser. William og Aber (2016) har sat spørgsmålstegn ved de generelle social-emotionelle konsekvenser og argumenterer for, at børn og unge generelt 
virker til at klare sig igennem deres sorg igennem støtte fra positive netværk og ressourcer (fx venner, fritidsinteresser, familie) i deres nærmiljø. Fokus bør derfor være at undersøge de specifikke årsager til, hvorfor et fåtal ikke gør.

En stor kohorteundersøgelse fra Kræftens Bekæmpelse (Høeg, Johansen, Christensen, Frederiksen, Dalton, Bøge et al., 2018), der omfattede den samlede danske befolkning ( $n=1.043 .813)$, født i perioden 1982-2000, undersøgte yderligere de uddannelsesmæssige konsekvenser af at miste en forælder før ens 18-års fødselsdag. Det blev konstateret, at sandsynligheden for at opnå et vist uddannelsesniveau var op til $5 \%$ lavere for folkeskolen og gymnasiet og $26 \%$ lavere for universitetsstudier sammenlignet med statistikker for ikke-efterladte børn. Unge mænd blev mere negativt påvirket end unge kvinder.

\section{Konklusion}

Denne litteraturgennemgang har påvist de mange konsekvenser, der følger med tabet af en forælder. Følgevirkningerne fordeler sig bredt over både fysiske, psykiske samt sociale parametre. Samtidigt viser særligt de sidste års forskning, hvordan de udfordringer, der følger med tabet af en forælder, kan associeres med en livslang overdisponering for at $\mathrm{d} \varnothing$ før tid. Som sådan er sorgens pris derfor til stede over en lang række parametre, og en opsummering over mulige udfordringer kan ses i figur 1.

Vi bør dog huske på, at selv om undersøgelser viser en statistisk overvægt af problemer hos børn, der mister deres forældre, vil de fleste børn klare sig godt både i barndommen og voksenlivet. Det betyder ikke, at de ikke kæmper med sorg over tid, men at de på sigt genoptager deres funktion og ofte formår at etablere et godt liv på trods af deres tab.

Denne litteraturgennemgang påviser yderligere, hvordan det kan være en stor udfordring at isolere sorgens konsekvenser fra de socioøkonomiske faktorer, der var tilstede i familien inden dødsfaldet, og de, som opstår som konsekvens af tabet. Meget forskning antyder, at disse faktorer i lige så høj grad, eller endda i højere grad, influerer og skaber de udfordringer, der følger med tabet.

Litteraturgennemgangen har i flere studier påvist metodiske svagheder såsom deltagergrupper, der er meget ens, kvota-sampling og forsimplede analytiske tilgange. Vi har ligeledes beskrevet et forskningsfelt, som til tider er plaget af begrebsmæssig inkonsistens. Selvom der igennem de sidste år er kommet en forøget interesse inden for sorgforskning, er der stadig behov for flere metodiske 
velfunderede studier af høj kvalitet, der kan bekræfte de sidste årtiers nye viden. Nuværende studier viser mange konsekvenser, men i de flestes tilfælde er de ikke reproducerede i tilstrækkelig grad. Særligt vil longitudinelle studier, der følger udviklingen og de forskellige veje igennem sorg her kunne give os yderligere dybde i vores forståelse.

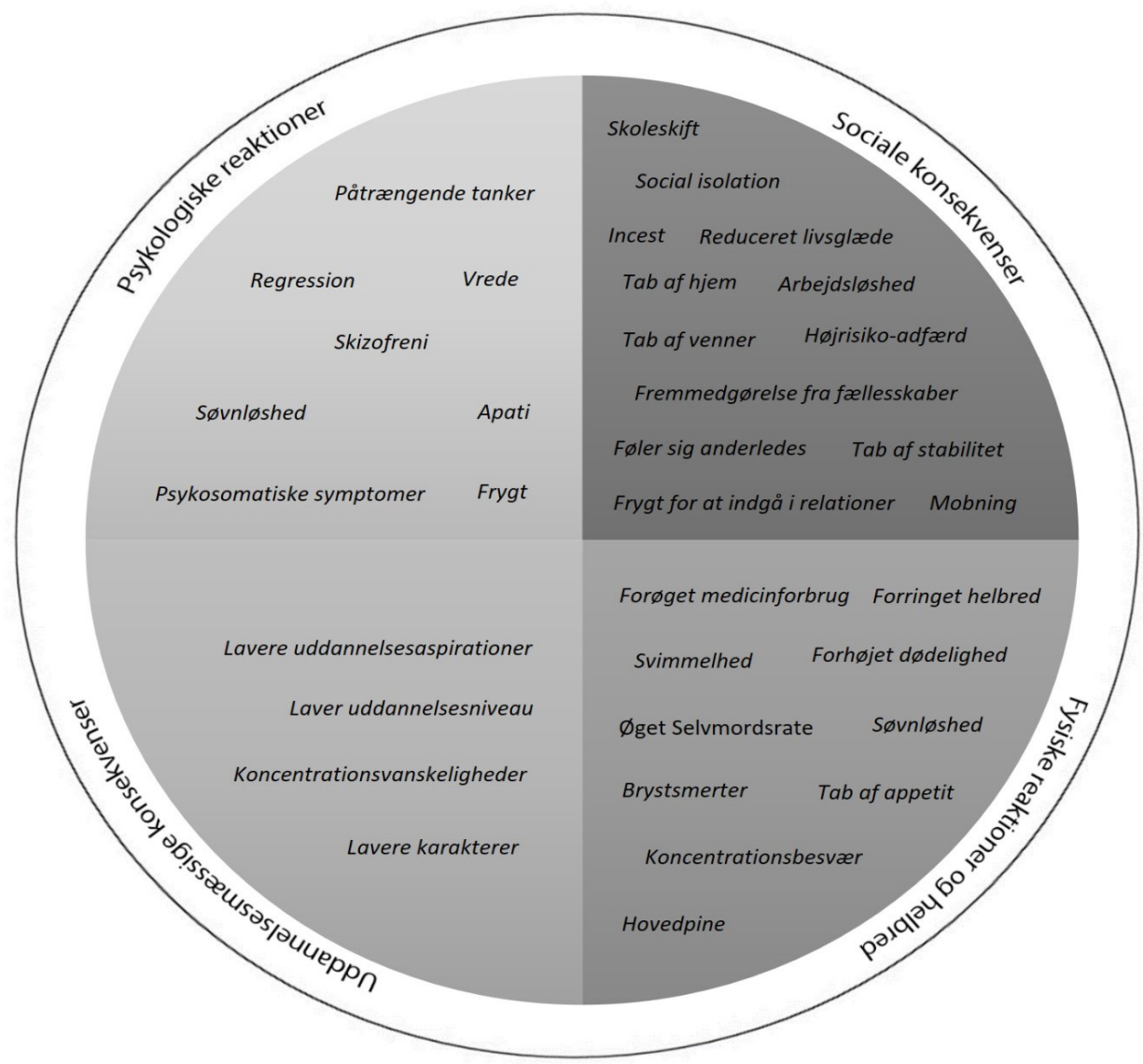

Figur 1: Sorgens pris - mulige udfordringer for børn, der har mistet en forælder

\section{Referencer}

Abdelnoor, A., \& Hollins, S. (2004). The effect of childhood bereavement on secondary school performance. Educational Psychology in Practice, 20(1), 43-54. https://doi. org/10.1080/0266736042000180401 
Agid, O., Shapira, B., Zislin, J., Ritsner, M., Hanin, B., Murad, H., \& Lerer, B. (1999). Environment and vulnerability to major psychiatric illness: A case control study of early parental loss in major depression, bipolar disorder and schizophrenia. Molecular Psychiatry, 4(2), 163-172. https://doi.org/10.1038/sj.mp.4000473

Akerman, R., \& Statham, J. (2014). Bereavement in childhood: The impact on psychological and educational outcomes and the effectiveness of support services. Childhood Wellbeing Research, Working Paper, (25), 1-37.

Appel, C. W., Johansen, C., Christensen, J., Frederiksen, K., Hjalgrim, H., Dalton, S. O., ... Bidstrup, P. E. (2016). Risk of use of antidepressants among children and young adults exposed to the death of a parent. Epidemiology, 27(4), 578-585. https://doi.org/10.1097/ EDE.0000000000000481

Auman, M. J. (2007). Bereavement support for children. The Journal of School Nursing, 23(1), 34-39. https://doi.org/10.1177/10598405070230010601

Baldessarini, R. J., \& Hennen, J. (2004). Genetics of Suicide: An Overview. Harvard Review of Psychiatry, 12(1), 1-13.

Balk, D. E. (2010). Children's Encounters with Death, Bereavement, and Coping. New York: Springer Publishing Company.

Berg, L., Rostila, M., \& Hjern, A. (2016). Parental death during childhood and depression in young adults - a national cohort study. Journal of Child Psychology and Psychiatry, 57(9), 1092-1098. https://doi.org/10.1111/jcpp.12560

Berg, L., Rostila, M., Saarela, J., \& Hjern, A. (2014). Parental death during childhood and subsequent school performance. Pediatrics, 133(4), 682-689. https://doi.org/10.1542/ peds.2013-2771

Black, D., Harris-Hendriks, J., \& Kaplan, T. (1992). Father kills mother: Post-traumatic stress disorder in the Children. Psychotherapy and Psychosomatics, 57(4), 152-157. https://doi. org/10.1159/000288592

Bondy, B., Buettner, A., \& Zill, P. (2006). Genetics of suicide. Molecular Psychiatry, 11(4), 336351. https://doi.org/10.1038/sj.mp.4001803

Brent, D., Melhem, N., Donohoe, M. B., \& Walker, M. (2009). The incidence and course of depression in bereaved youth 21 months after the loss of a parent to suicide, accident, or sudden natural death. Am J Psychiatry, 166(7), 786-794. https://doi.org/10.1176/appi. ajp.2009.08081244

Brent, D., Melhem, N. M., Masten, A. s., Porta, G., \& Payne, M. W. (2012). Longitudinal effects of parental bereavement on adolescent developmental competence. Journal of Clinical Child \& Adolescent Psychology, 41(6), 778-791. https://doi.org/10.1080/15374416.2 012.717871

Bryant, R. A. (2014). Prolonged grief: where to after Diagnostic and Statistical Manual of Mental Disorders. Current Opinion in Psychiatry, 27(1), 21-26. https://doi.org/10.1097/ YCO.0000000000000031

Burrell, L. V., Mehlum, L., \& Qin, P. (2017). Risk factors for suicide in offspring bereaved by sudden parental death from external causes. Journal of Affective Disorders, 222, 71-78. https://doi.org/10.1016/j.jad.2017.06.064

Bylund-Grenklo, T., Fürst, C. J., Nyberg, T., Steineck, G., \& Kreicbergs, U. (2016). Unresolved grief and its consequences. A nationwide follow-up of teenage loss of a parent to cancer 6-9 years earlier. Supportive Care in Cancer, 24(7), 3095-3103. https://doi.org/10.1007/ s00520-016-3118-1 
Bylund-Grenklo, T. N., Kreicbergs, U., Hauksdóttir, A., Valdimardóttir, U. A., Nyberg, T., Steineck, G. \& Fürst, C. J. (2013). Self-injury in teenagers who lost a parent to cancer. A nationwide, population-based, long-term follow-up. Journal of the American Medical Association: Pediatrics, 167, (2), 133-140. https://doi.org/10.1001/jamapediatrics.2013.430

Bylund Grenklo, T., Kreicbergs, U., Valdimarsdóttir, U. A., Nyberg, T., Steineck, G. \& Fürst, C. J. (2014). Self-injury in youths who lost a parent to cancer: nationwide study of the impact of family-related and health-care-related factors. Psycho-Oncology, 23(9), 989997. http://doi.org/10.1002/pon.3515 https://doi.org/10.1002/pon.3515

Cerel, J., Fristad, M. A., Verducci, J., Weller, R. A., \& Weller, E. B. (2006). Childhood bereavement: Psychopathology in the 2 years postparental death. Journal of the American Academy of Child \& Adolescent Psychiatry, 45(6), 681-690. https://doi.org/10.1097/01. chi.0000215327.58799.05

Clark, C. D., Caldwell, T., Power, C., \& Stansfeld, S. A. (2010). Does the influence of childhood adversity on psychopathology persist across the lifecourse? A 45-year prospective epidemiologic study. Annals of Epidemiology, 20(5), 385-394. https://doi.org/10.1016/j. annepidem.2010.02.008

Cross, S., \& Harrison, H. (Eds.). (2002). »I can't stop feeling sad « Calls to ChildLine about bereavement. London: ChildLine.

Currier, J. M., Neimeyer, R. A., \& Berman, J. S. (2008). The effectiveness of psychotherapeutic interventions for bereaved persons: A comprehensive quantitative review. Psychological Bulletin, 134(5), 648-661. https://doi.org/10.1037/0033-2909.134.5.648

Dennehy, C. M. (1966). Childhood Bereavement and Psychiatric Illness. The British Journal of Psychiatry, 112(491), 1049-1069. https://doi.org/10.1192/bjp.112.491.1049

Diekstra, R. F. W., \& Hawton, K. E. (2012). Suicide in Adolescence. Amsterdam: Springer Science \& Business Media.

Dopp, A. R., \& Cain, A. C. (2012). The Role of Peer Relationships in Parental Bereavement During Childhood and Adolescence. Death Studies, 36(1), 41-60. https://doi.org/10.1080/ 07481187.2011.573175

Dowdney, L. (2000). Annotation: Childhood bereavement following parental death. The Journal of Child Psychology and Psychiatry and Allied Disciplines, 41(07), 819-830. https:// doi.org/10.1111/1469-7610.00670

Dowdney, L., Wilson, R., Maughan, B., Allerton, M., Schofield, P., \& Skuse, D. (1999). Psychological disturbance and service provision in parentally bereaved children: Prospective case-control study. BMJ, 319(7206), 354-357. https://doi.org/10.1136/bmj.319.7206.354

Dyregrov, A. (2008). Grief in Children, Second Edition: A Handbook for Adults (2. edition). London; Philadelphia: Jessica Kingsley Publishers.

Dyregrov, A., \& Dyregrov, K. (2008). Effective Grief and Bereavement Support: The Role of Family, Friends, Colleagues, Schools and Support Professionals. London: Jessica Kingsley Publishers.

Dyregrov, A., Dyregrov, K., Endsjø, M., \& Idsoe, T. (2015). Teachers' perception of bereaved children's academic performance. Advances in School Mental Health Promotion, 0(0), 1-12. https://doi.org/10.1080/1754730X.2015.1051888

Dyregrov, A. (2004). Educational consequences of loss and trauma. Educational and Child Psychology, 21(3), 77.

Dyregrov, K. (2004). Bereaved parents' experience of research participation. Social Science $\mathcal{E}$ Medicine, 58(2), 391-400. https://doi.org/10.1016/S0277-9536(03)00205-3 
Dyregrov, K. (2009). The important role of the school following suicide in Norway. What support do young people wish that school could provide? OMEGA - Journal of Death and Dying, 59(2), 147-161. https://doi.org/10.2190/OM.59.2.d

Dyregrov, K., \& Dyregrov, A. (2005). Siblings after suicide - »The forgotten bereaved.« Suicide and Life-Threatening Behavior, 35(6), 714-724. https://doi.org/10.1521/suli.2005.35.6.714

Dyregrov, K., \& Dyregrov, A. (2011). Barn og unge som pårørende ved kreft. Hvordan kan barns situasjon og foreldres omsorgskapasitet styrkes i et rehabiliteringsperspektiv. Norway: Center for Crisis Psychology.

Gerard, J. M., \& Buehler, C. (2004). Cumulative environmental risk and youth maladjustment: The role of youth attributes. Child Development, 75(6), 1832-1849. https://doi. org/10.1111/j.1467-8624.2004.00820.x

Gersten, J. C., Beals, J., \& Kallgren, C. A. (1991). Epidemiology and preventive interventions: Parental death in childhood as a case example. American Journal of Community Psychology, 19(4), 481-500. https://doi.org/10.1007/BF00937988

Gray, L. B., Weller, R. A., Fristad, M., \& Weller, E. B. (2011). Depression in children and adolescents two months after the death of a parent. Journal of Affective Disorders, 135(1), 277-283. https://doi.org/10.1016/j.jad.2011.08.009

Green, E. J., \& Connolly, M. E. (2009). Jungian family sandplay with bereaved children: Implications for play therapists. International Journal of Play Therapy, 18(2), 84-98. https:// doi.org/10.1037/a0014435

Greeson, J. K. P., Briggs, E. C., Layne, C. M., Belcher, H. M. E., Ostrowski, S. A., Kim, S., ... Fairbank, J. A. (2014). Traumatic Childhood Experiences in the 21st Century: Broadening and Building on the ACE Studies With Data From the National Child Traumatic Stress Network. Journal of Interpersonal Violence, 29(3), 536-556. https://doi. org/10.1177/0886260513505217

Greenhalgh, T., Thorne, S., \& Malterud, K. (2018). Time to challenge the spurious hierarchy of systematic over narrative reviews? European Journal of Clinical Investigation, e12931.

Guldin, M.-B., Li, J., Pedersen, H. S., Obel, C., Agerbo, E., Gissler, M., ... Vestergaard, M. (2015). Incidence of suicide among persons who had a parent who died during their childhood: A population-based cohort study. JAMA Psychiatry, 72(12), 1227-1234. https://doi.org/10.1001/jamapsychiatry.2015.2094

Hamdan, S., Mazariegos, D., Melhem, N. M., Porta, G., Payne, M. W. \& Brent, D. A. (2012). Effect of parental bereavement on health risk behaviors in youth. A 3-year follow-up. Archives of Pediatrics \& Adolescent Medicine, 166(3), 216-223. https://doi.org/10.1001/archpediatrics.2011.682

Harrison, L., \& Harrington, R. (2001). Adolescents' bereavement experiences. Prevalence, association with depressive symptoms, and use of services. Journal of Adolescence, 24(2), 159-169. https://doi.org/10.1006/jado.2001.0379

Hayslip, B., Pruett, J. H., \& Caballero, D. M. (2015). The »How« and »When« of parental loss in adulthood effects on grief and adjustment. OMEGA - Journal of Death and Dying, 71(1), 3-18. https://doi.org/10.1177/0030222814568274

Høeg, B. L., Appel, C. W., Heymann-Horan, A. B., Frederiksen, K., Johansen, C., Bøge, P., Bidstrup, P. E. (2016). Maladaptive coping in adults who have experienced early parental loss and grief counseling. Journal of Health Psychology, Advance online publication.

Høeg, B. L., Johansen, C., Christensen, J., Frederiksen, K., Dalton, S. O., Dyregrov, A., ... Bidstrup, P. E. (2018). Early Parental Loss and Intimate Relationships in Adulthood: A 
Nationwide Study. Developmental Psychology. Advance online publication. https://doi. org/10.1037/dev0000483

Høeg, B. L., Johansen, C., Christensen, J., Frederiksen, K., Dalton, S. O., Bøge, P., ... Bidstrup, P. E. (2018). Does losing a parent early influence the education you obtain? A nationwide cohort study in Denmark. Journal of Public Health

Holland, J. (2008). How schools can support children who experience loss and death. British Journal of Guidance E Counselling, 36(4), 411-424.https://doi.org/10.1080/03069880802364569

Jakobsen, I. S. \& Christiansen, E. (2011). Young people's risk of suicide attempts in relation to parental death: a population-based register study. Journal of Child Psychology and Psychiatry, 52:2, 176-83 https://doi.org/10.1111/j.1469-7610.2010.02298.

Koenen, K. C., Moffitt, T. E., Poulton, R., Martin, J., \& Caspi, A. (2007). Early childhood factors associated with the development of post-traumatic stress disorder: results from a longitudinal birth cohort. Psychological Medicine, 37(2), 181-192. https://doi.org/10.1017/ S0033291706009019

Krause, N. (1998). Early parental loss, recent life events, and changes in health among older adults. Journal of Aging and Health, 10(4), 395-421. https://doi. org/10.1177/089826439801000401

Kravdal, Ø., \& Grundy, E. (2016). Health effects of parental deaths among adults in Norway: Purchases of prescription medicine before and after bereavement. SSM - Population Health, 2, 868-875. https://doi.org/10.1016/j.ssmph.2016.10.013

Kristensen, P., Dyregrov, K., \& Dyregrov, A. (2017). Hva skiller forlenget sorg-forstyrrelse fra depresjon? Tidsskrift for Den norske legeforening, 137, 538-539.

Lee, K.-Y., Li, C.-Y., Chang, K.-C., Lu, T.-H., \& Chen, Y.-Y. (2017). Age at exposure to parental suicide and the subsequent risk of suicide in young people. Crisis, Advance Online Publication,1-10. DOI: 10.1027/0227-5910/a000468 https://doi.org/10.1027/0227-5910/a000468

Li, J., Vestergaard, M., Cnattingius, S., Gissler, M., Bech, B. H., Obel, C., \& Olsen, J. (2014). Mortality after parental death in childhood: A nationwide cohort study from three Nordic countries. PLoS Medicine, 11, e1001679. https://doi.org/10.1371/journal.pmed.1001679

Liang, H., Olsen, J., Yuan, W., Cnattingus, S., Vestergaard, M., Obel, C., ... Li, J. (2016). Early life bereavement and schizophrenia: A nationwide cohort study in Denmark and Sweden. Medicine, 95(3), e2434. https://doi.org/10.1097/MD.0000000000002434

Liu, X., Olsen, J., Agerbo, E., Yuan, W., Cnattingius, S., Gissler, M., \& Li, J. (2013). Psychological stress and hospitalization for childhood asthma- A nationwide cohort study in two Nordic countries. PLOS ONE, 8(10), e78816. https://doi.org/10.1371/journal.pone.0078816

Luecken, L. J. (2008). Long-term consequences of parental death in childhood: Psychological and physiological manifestations. In M. S. Stroebe, R. O. Hansson, W. Stroebe, \& H. Schut (Eds.), Handbook of Bereavement Research and Practice: Advances in Theory and Intervention, (s. 397-416).

Luecken, L. J., \& Roubinov, D. S. (2012). Pathways to lifespan health following childhood parental death. Social and Personality Psychology Compass, 6(3), 243-257. https://doi. org/10.1111/j.1751-9004.2011.00422.x

Lundorff, M., Holmgren, H., Zachariae, R., Farver-Vestergaard, I., \& O'Connor, M. (2017). Prevalence of prolonged grief disorder in adult bereavement: A systematic review and meta-analysis. Journal of Affective Disorders, 212, 138-149. https://doi.org/10.1016/j. jad.2017.01.030 
Lytje, M. (2016a). Unheard Voices: Parentally Bereaved Danish Students' Experiences and Perceptions of the Support Received Following the Return to School. (Doctorial Dissertation). University of Cambridge, Cambridge.

Lytje, M. (2016b). Voices We Forget -Danish Students Experience of Returning to School Following Parental Bereavement. OMEGA - Journal of Death and Dying. Advance Online Publication. DOI: 10.1177/0030222816679660 https://doi.org/10.1177/0030222816679660

Mack, K. Y. (2001). Childhood family disruptions and adult well-being: the differential effects of divorce and parental death. Death Studies, 25(5), 419-443. https://doi. org/10.1080/074811801750257527

Mackenbach, J. P., Stirbu, I., Roskam, A.-J. R., Schaap, M. M., Menvielle, G., Leinsalu, M., \& Kunst, A. E. (2008). Socioeconomic inequalities in health in 22 European countries. New England Journal of Medicine, 358(23), 2468-2481. https://doi.org/10.1056/NEJMsa0707519

McClatchey, I. S., Vonk, M. E., Lee, J., \& Bride, B. (2014). Traumatic and complicated grief among children: One or two constructs? Death Studies, 38(2), 69-78. https://doi.org/10.10 80/07481187.2012.725571

MacLure, M. (2005). ‘Clarity bordering on stupidity': where’s the quality in systematic review? Journal of Education Policy, 20(4), 393-416. https://doi.org/10.1080/02680930500131801

Mallon, B. (2010). Working with Bereaved Children and Young People. Thousand Oaks: SAGE.

Mann, J. J., Brent, D. A., \& Arango, V. (2001). The neurobiology and genetics of suicide and attempted suicide: a focus on the serotonergic system. Neuropsychopharmacology, 24(5), 466-77. https://doi.org/10.1016/S0893-133X(00)00228-1

Mays, N., Pope, C., \& Popay, J. (2005). Systematically reviewing qualitative and quantitative evidence to inform management and policy-making in the health field. Journal of Health Services Research \& Policy, 10, 6-20. https://doi.org/10.1258/1355819054308576

McGuffin, P., Marušič, A., \& Farmer, A. (2001). What can psychiatric genetics offer suicidology? Crisis: The Journal of Crisis Intervention and Suicide Prevention, 22(2), 61-65. https://doi.org/10.1027//0227-5910.22.2.61

Melhem, N. (2008). Antecedents and sequelae of sudden parental death in offspring and surviving caregivers. Archives of Pediatrics \& Adolescent Medicine, 162(5), 403-410. https:// doi.org/10.1001/archpedi.162.5.403

Melhem, N. M., Porta, G., Shamseddeen, W., Payne, M. W., \& Brent, D. A. (2011). Grief in children and adolescents bereaved by sudden parental death. Archives of General Psychiatry, 68(9), 911-919. https://doi.org/10.1001/archgenpsychiatry.2011.101

Mittendorfer-Rutz, E., Rasmussen, F., \& Wasserman, D. (2008). Familial clustering of suicidal behaviour and psychopathology in young suicide attempters. Social Psychiatry and Psychiatric Epidemiology, 43(1), 28-36. https://doi.org/10.1007/s00127-007-0266-0

Moor, N., \& Graaf, P. M. de. (2016). Temporary and long-term consequences of bereavement on happiness. Journal of Happiness Studies, 17(3), 913-936. https://doi.org/10.1007/s10902015-9624-x

Mulrow, C. D., \& Cook, D. (1998). Systematic Reviews: Synthesis of Best Evidence for Health Care Decisions. Philadelphia: ACP Press.

Neeleman, J., Sytema, S., \& Wadsworth, M. (2002). Propensity to psychiatric and somatic ill-health: evidence from a birth cohort. Psychological Medicine, 32(5), 793-803. https:// doi.org/10.1017/S0033291702005901

Niederkrotenthaler, T., Floderus, B., Alexanderson, K., Rasmussen, F. \& Mittendorfer-Rutz, E. (2012). Exposure to parental mortality and markers of morbidity, and the risks of 
attempted and completed suicide in offspring: An analysis of sensitive life periods. Journal of Epidemiology and Community Health, 66(3), 233-239. https://doi.org/10.1136/ jech.2010.109595

Nielsen, J. C., Sørensen, N. U., \& Hansen, N. M. (2012). Unge pårørende og efterladtes trivsel. Center for ungdomsforskning: Aarhus: Aarhus Universitet.

Otowa, T., York, T. P., Gardner, C. O., Kendler, K. S., \& Hettema, J. M. (2014). The impact of childhood parental loss on risk for mood, anxiety and substance use disorders in a population-based sample of male twins. Psychiatry Research, 220(1-2), 404-409. https:// doi.org/10.1016/j.psychres.2014.07.053

Packman, W., Horsley, H., Davies, B., \& Kramer, R. (2006). Sibling bereavement and continuing bonds. Death Studies, 30(9), 817-841. https://doi.org/10.1080/07481180600886603

Parkes, C. M., \& Weiss, R. S. (1983). Recovery from Bereavement. London: Basic Books.

Parsons, S. (2011). Long Term Outcomes of Parental Bereavement. University of Kent: Childhood Wellbeing Research Center.

Pearlman, M. Y., Schwalbe, K. D. \& Cloitre, M. (2010). Grief in Childhood. Fundamentals of Treatment in Clinical Practice. Washington: American Psychological Association. https:// doi.org/10.1037/12131-000

Prix, I., \& Erola, J. (2017). Does death really make us equal? Educational attainment and resource compensation after paternal death in Finland. Social Science Research, 64, 171183. https://doi.org/10.1016/j.ssresearch.2016.10.012

Phillips, F. (2014). Adolescents living with a parent with advanced cancer: a review of the literature. Psycho-Oncology, 23(12), 1323-1339. https://doi.org/10.1002/pon.3570

Rostila, M., Berg, L., Arat, A., Vinnerljung, B., \& Hjern, A. (2016). Parental death in childhood and self-inflicted injuries in young adults-a national cohort study from Sweden.

European Child E Adolescent Psychiatry, 25(10), 1103-1111. https://doi.org/10.1007/s00787016-0833-6

Rostila, M., \& Saarela, J. M. (2011). Time does not heal all wounds: Mortality following the death of a parent. Journal of Marriage and Family, 73(1), 236-249. https://doi.org/10.1111/ j.1741-3737.2010.00801.x

Silverman, P. R., \& William, J. (1992). Children's reactions in the early months after the death of a parent. American Journal of Orthopsychiatry, 62(1), 93-104. https://doi.org/10.1037/ h0079304

Silverman, P. R., \& Worden, J. W. (1993). Children's Reactions to the Death of a Parent. In M. Stroebe, W. Stroebe, \& R. O. Hanson (Eds.), Handbook of Bereavement Theory, Research, and Interventions (s. 300-316). New York: Cambridge University Press. https://doi. org/10.1017/CBO9780511664076.021

Smith, K. R., Hanson, H. A., Norton, M. C., Hollingshaus, M. S., \& Mineau, G. P. (2014). Survival of offspring who experience early parental death: early life conditions and later-life mortality. Social Science \& Medicine (1982), 119, 180-190. https://doi.org/10.1016/j. socscimed.2013.11.054

Stroebe, M. S., Schut, H., \& Stroebe, W. (2007). Health outcomes of bereavement. The Lancet, 370(9603), 1960-1973. https://doi.org/10.1016/S0140-6736(07)61816-9

Tebeka, S., Hoertel, N., Dubertret, C., \& Le Strat, Y. (2016). Parental divorce or death during childhood and adolescence and its association with mental health. The Journal of Nervous and Mental Disease, 204(9), 678-685. https://doi.org/10.1097/NMD.0000000000000549 
Uman, L. S. (2011). Systematic Reviews and Meta-Analyses. Journal of the Canadian Academy of Child and Adolescent Psychiatry, 20(1), 57-59.

US Bureau of the Census (1990) Statistical abstracts of the US 1990. Washington (D.C.): US Government Printing Office.

Williams, L. D., \& Aber, J. L. (2016). Testing for plausibly causal links between parental bereavement and child socio-emotional and academic outcomes: A propensity-score matching model. Journal of abnormal child psychology, 44, 705-718. https://doi.org/10.1007/ s10802-015-0069-9

Worden, W. (1996). Children and grief: When a parent dies. New York: Guilford Press. 